\title{
Fermentasi Biji Kakao Kering Menggunakan Saccharomyces cerevisiae, Lactobacillus lactis, dan Acetobacter aceti
}

\author{
Cocoa Beans Dry Fermentation Using Saccharomyces cerevisiae, Lactobacillus lactis, and Acetobacter aceti
}

\author{
Mulono Apriyanto* ${ }^{1 *}$ S. Sutardi ${ }^{2}$, S. Supriyanto ${ }^{2}$, Eni Harmayani ${ }^{2}$ \\ 'Jurusan Teknologi Pangan, Fakultas Pertanian, Universitas Islam Indragiri, \\ Jl. Propinsi Parit 1 Tembilahan, Indragiri Hilir, Riau, Indonesia 29213 \\ ${ }^{2}$ Departemen Teknologi Pangan dan Hasil Pertanian, Fakultas Teknologi Pertanian, Universitas Gadjah Mada, \\ Jl. Flora No. 1, Bulaksumur, Yogyakarta 55281, Indonesia \\ Email: pandumulono@gmail.com
}

Submisi: 17 Februari 2016; Penerimaan: 18 Mei 2017

\begin{abstract}
ABSTRAK
Penelitian ini bertujuan untuk mengetahui perubahan sifat kimia pada fermentasi biji kakao kering jemur. Biji kakao kering jemur yang diperoleh dari petani memiliki kadar air yang tidak seragam. Guna menimalkan kegagalan fermentasi maka biji kakao kering jemur diperoleh melalui pengeringan biji kakao segar menggunakan kabinet dryer dengan sebelumnya dikondisikan pada suhu seperti pengeringan dengan sinar matahari, dan masing ditentukan kadar gula reduksinya. Percobaan fermentasi biji kakao kering dilakukan fermentasi pada wadah fermentasi dengan jumlah biji $150 \mathrm{~g}$ setiap wadah. Sebelum difermentasi terlebih dahulu biji kakao kering jemur direhidrasi agar didapat kadar air mendekati biji segar, kemudian biji kakao kering jemur diinkubasi selama enam hari dan tanpa dibalik selama fermentasi. Setiap perlakuan diulangi tiga kali dan diamati tiap 24 jam sampai 120 jam. Kadar gula reduksi (kontrol 4,49-11,45\%, inokulum diawal (IA) 4,69-11,55\%, inokulum bertahap (IB) 4,64-11,54\%), kadar asam tertitrasi (kontrol 4,48-6,45\%, inokulum diawal (IA) 4,64-6,39\%, inokulum bertahap (IB) 4,45-6,59\%), populasi Saccharomycescerevisiae (kontrol 5,56-7,28 (log CFU/g), inokulum diawal (IA) 6,45-8,75 (logCFU/g), inokulum bertahap (IB) $6.88-8.99$ (logCFU/g), Lactobacillus lactis (kontrol 6,66-8,15 (log CFU/g), inokulum diawal (IA) 7,65-8,21(log CFU/g), inokulum bertahap (IB) 7,66-8,95 (log CFU/g) dan Acetobacter aceti (kontrol 4,26-6,95\% (log CFU/g), inokulum diawal (IA) 4,85-7,40 $(\log \mathrm{CFU} / \mathrm{g})$, inokulum bertahap (IB) 4,35-7,91 $(\log \mathrm{CFU} / \mathrm{g})$ ) dalam pulp fermentasi diamati selama proses fermentasi. Untuk mengetahui kualitas biji kakao dilakukan pengukuran $\mathrm{pH}$ (kontrol 5,67-3,98, inokulum diawal (IA) 5,67-3,55, inokulum bertahap (IB) 5,67-3,50), kadar etanol (kontrol 0,3-0,5\%, inokulum diawal (IA) 0,3-0,52\%, inokulum bertahap (IB) $0,35-0,53 \%$ ) dan indeks fermentasi selama fermentasi (kontrol 0,31-0,88, inokulum diawal (IA) $0,32-$ 0,99 , inokulum bertahap (IB) $0,33-1,03$ ).
\end{abstract}

Kata kunci: Acetobacter aceti; biji kakao kering jemur; fermentasi; Lactobacillus lactis; Saccharomyces cerevisiae

\begin{abstract}
The aims of the study was to improve quality of cocoa bans by fermentation of sun dried cocoa beans. The fermentation variations were conducted as follows: first, fermentation without the addition of inoculum (control), the second treatment using inoculum of S. cerevisiae (FNCC 3056), L. lactis (FNC 0086) and A. aceti (FNCC 0016), each of $10^{8}$ $\mathrm{cfu} / \mathrm{g}$ given simultaneously at the beginning of fermentation.and the third treatment wassequential administration, i.e: yeast at the initial fermentation, lactic acid bacteria after 24 hours fermentation, and acetic acid bacteria after $48 \mathrm{hr}$
\end{abstract}


of fermentation third with the same microbial population with the second treatment. The fermentation was conducted for 120 hours. The fermentation temperature were controlled during fermentation as follows: $35^{\circ} \mathrm{C}$ for the first 24 hours, $45^{\circ} \mathrm{C}$ for the next second 24 - hours, $55^{\circ} \mathrm{C}$ the third 24 hours and $35^{\circ} \mathrm{C}$ for the last 48 hours of fermentation. The results showed that after the rehydration, pulp composition of dry beans could be used as a substrate for fermentation. During fermentation, dry cocoa beans showed reduction of total sugar content, $\mathrm{pH}$ and total polyphenols for all the three treatments. Cut test of dried cocoa beans during the fermentation showed the increasing percentage of brown color of the three treatments. Reducing sugar and fermentation indexes increasedfor all treatments during fermentation. Concentration of ethanol, lactic acid and acetic acid reached highest level at 24, 60, and 108 hours of fermentationfor all treatments. Highest populations of S. cerevisiae, L. lactis and A. aceti of three treatments obtained at 24, 48 and 72 hours of fermentation. After fermentation and roasting, dry beans produced hydrophobic amino acids as precursors of flavor and volatile compounds.

Keywords: Acetobacter aceti; dry beansdrying; fermentation; Lactobacillus lactis; Saccharomyces cerevisiae

\section{PENDAHULUAN}

Ada dua cara penanganan pasca panen biji kakao segar (basah) ditingkat petani yaitu produksi biji kakao kering jemur "dengan fermentasi" dan biji kakao kering jemur tanpa fermentasi. Menurut Badan Pendataan Statistik (Anonim, 2013), produksi kakao kering pada tahun 2013 mencapai \pm 5.450 .000 ton tanpa fermentasi sedangkan \pm 385.000 ton merupakan biji kakao kering hasil fermentasi. Biji kakao kering jemur tanpa fermentasi terdiri atas biji kakao kering jemur (produksi petani) dan biji kakao kering jemur setengah fermentasi. Pada umumnya petani kakao hanya merendam biji kakao segar dalam air dalam upaya untuk membantu menghilangkan pulp dan dilanjutkan penjemuran (Apriyanto dkk, 2016a; Anonim, 2013).

Fermentasi adalah proses perombakan gula dan asam sitrat dalam pulp menjadi asam-asam organik yang dilakukan oleh mikrobia pelaku fermentasi (Camu, dkk., 2008., Meersman dkk, 2013). Asam-asam organik tersebut akan menginduksi reaksi enzimatik yang ada di dalam biji sehingga terjadi perubahan biokimia yang akan membentuk senyawa yang memberi aroma, rasa, dan warna pada kakao (Apriyanto dkk., 2016b; Afoakwa dkk., 2014). Proses fermentasi terbagi 3 tahapan (Albertini dkk, 2015) yaitu: (1) Tahap anaerobic terjadi pada 24-36 jam pertama. Yeast akan mengkonversi gula menjadi alkohol dalam kondisi rendah oksigen dan $\mathrm{pH}$ dibawah 4, (2) Tahap Lactobacillus lactis yang keberadaannya mulai dari awal fermentasi, tetapi hanya menjadi dominan antara 48 dan 96 jam. Lactobacillus lactis mengkonversi gula dan sebagian asam organik menjadi asam laktat, (3) Tahap bakteri asam asetat, dimana keberadaan bakteri asam asetat juga terjadi selama fermentasi, tetapi menjadi sangat signifikan hingga akhir ketika terjadi peningkatan aerasi. Bakteri asam asetat berperan dalam mengkonversi alkohol menjadi asam asetat. Konversi tersebut akibat reaksi eksotermik yang sangat kuat yang berperan dalam peningkatan suhu. Pada tahap ini suhu bisa mencapai $50{ }^{\circ} \mathrm{C}$ atau lebih tinggi pada sebagian fermentasi. Proses ini dilakukan dengan cara memeram biji kakao pada wadah tertutup selama 5-7 hari dengan disertai pembalikan setiap 2 hari sekali. Tanpa melalui proses fermentasi biji kakao akan terasa pahit, sepat, dan tidak akan menghasilkan aroma khas cokelat ketika diolah (Schwan dan Wheals, 2004).

Biji kakao kering telah kehilangan sebagian besar kandungan air dan substrat. Kandungan air selama fermentasi digunakan dalam reaksi enzimatik dalam biji dan pertumbuhan mikrobia di dalam pulp (Schwan dan Wheals, 2004). Air akan mempertemukan enzim dengan substrat yang ada di dalam biji sehingga proses hidrolisis dan oksidasi senyawa calon rasa, warna, dan aroma pada kakao dapat terjadi. Kandungan air yang dibutuhkan dalam fermentasi kakao adalah lebih dari $35 \%$. Substrat adalah bahan yang dirombak oleh mikrobia selama proses fermentasi. Substrat dalam fermentasi biji kakao adalah gula dan asam sitrat yang terkandung dalam pulp.

Mikrobia akan melakukan perombakan senyawa gula dalam pulp menjadi asam-asam organil selama fermentasi. Asam akan berdifusi masuk ke dalam biji dan menginduksi reaksi enzimatik untuk membentuk senyawa calon rasa, aroma, dan warna (Afoakwa dkk., 2014). Menurut Shwan dan Wheals (2004), keberhasilan fermentasi biji kakao diperngaruhi oleh subtrat dan jumlah mikrobia selama fermentasi. Berdasarkan hal diatas, maka perlu diupayakan pengembalian kandungan air biji kakao sebelum fermentasi. Penelitian fermentasi kakao menggunakan biji kakao kering jemur telah berhasil dilakukan di laboratorium rekayasa PAU, UGM. Penelitian ini bertujuan untuk mengetahui perubahan sifat kimia pada fermentasi biji kakao kering jemur. 


\section{METODE PENELITIAN}

\section{Biji Kakao Kering}

Buah kakao varietas forastero diperoleh dari desa Bunder, Patuk, Gunung Kidul, Yogyakarta memiliki karakteristik panjang buah $\pm 15 \mathrm{~cm}$, diameter $\pm 8 \mathrm{~cm}$, kulit buah masak optimal berwarna orange, jumlah biji tiap pod \pm 35 keping biji. Buah tanpa dicuci kemudian dibelah untuk dikeluarkan bijinya dan dikeringkan pada cabinet dryer dengan suhu 40 ${ }^{\circ} \mathrm{C}$ hingga kadar air biji menjadi 15\%. Sebanyak $100 \mathrm{~g}$ biji kakao kering dibasahi dengan air sebanyak $60 \mathrm{~mL}$ selanjutnya difermentasi selama 5 hari (120 jam) secara spontan pada suhu kamar dan diambil data perubahan gula reduksi, kandungan etanol, dan suksesi mikrobia selama fermentasi untuk menentukan kualitas hasil fermentasi diukur $\mathrm{pH}$ dan keasaman biji dan indeks fermentasi.

\section{Analisis Pendahuluan}

Analisis pendahuluan dilakukan untuk mengetahui kadar air dan gula reduksi pada pulp dan biji kakao yang hilang selama proses pengeringan. Kadar air biji kakao ditentukan dengan menggunakan metode gravimetri, sedangkan kadar gula reduksi pulp basah, pulp kering menggunkan metoda Nelson-Somogy (Sudarmadji dkk., 1997).

\section{Fermentasi Biji Kakao Kering}

Fermentasi biji kakao kering jemur dilakukan pada botol sampel ukuran $250 \mathrm{~mL}$ dengan jumlah biji kakao kering jemur sebanyak $150 \mathrm{~g}$ /botol sampel. Jumlah biakan murni khamir dan bakteri asam asetat yang ditambahkan (10s CFU/g) berdasarkan jumlah biakan murni yang ditambahkan pada fermentasi kakao biasa (Meersman dkk, 2013), sedangkan jumlah air yang ditambahkan berdasarkan selisih berat biji kakao segar dan biji kakao kering jemur jemur.

Fermentasi yang dilakukan dengan tiga cara yaitu: (1) biji kakao tanpa penambahan biakan murni (kontrol), (2) biji kakao ditambahkan campuran biakan murni (IA),(3) biji kakao ditambahkan biakan murni secara bertahap diawal fermentasi ditambahkan Saccharomyces cerevisiae, setelah jam ke 24 ditambahkan Lactobacillus lactis kemudian setelah 48 jam ditambahkan Acetobacter aceti (IB) (Apriyanto dkk., 2016a).

\section{Analisis Pemantauan Proses Fermentasi}

Kadar asam tertitrasi ditentukan dengan metode (Nazaruddin dkk., 2006), kadar gula reduksi ditentukan dengan metode Nelson-Somogy (Sudarmadji dkk., 1997). pH dankeasaman biji kakao kering selamafermentasi menggunakan metoda Nasarudin dkk. (2006), dan indeks fermentasi menggunakan metoda Misnawi dkk. (2002).
Data dianalisis menggunakan Duncan Multiple Range Test (DMRT).

\section{HASIL DAN PEMBAHASAN}

\section{Perubahan Kandungan Gula Reduksi}

Gula reduksi merupakan hasil perombakan pektin, pati, dan sukrosa yang terkandung dalam pulp dan tetes tebu oleh mikrobia selama fermentasi. Gula reduksi selain berfungsi sebagai bahan mentah pembentukan etanol juga berfungsi sebagai senyawa calon rasa dalam biji kakao. Kandungan gula reduksi pada fermentasi biji kakao kering jemur meningkat pada awal fermentasi dan menurun pada pertengahan fermentasi dan tetap stabil hingga akhir masa fermentasi (Afoakwa dkk., 2013).

Gula reduksi adalah senyawa karbonil prekursor aroma dalam biji kakao fermentasi, yang terutama dihasilkan dari hidrolisis sukrosa oleh enzim invertase (Neilsen dkk., 2013; Afoakwa, 2010). Hasil uji DMRT menunjukan bahwa lama fermentasi berpengaruh pada gula reduksi. Gula reduksi biji kakao kering jemur diawal fermentasi 4,5 $\pm 0,1$ naik menjadi $11,45 \pm 0,1$ pada 24 jam fermentasi selanjutnya terus turun sampai 10,6 $\pm 0,1$ di 120 jam fermentasi. Gula reduksi pulp biji kakao kering jemur selama fermentasi turun, di awal fermentasi 4,7 $\pm 0,1$ turun menjadi 2,8 $\pm 0,1$ di 24 jam fermentasi setelah 24 jam fermentasi terus turun menjadi 1,5 $\pm 0,1$ di 120 jam fermentasi. Gula reduksi biji kakao segar di awal fermentasi $7 \pm 0,1$ naik menjadi $12,5 \pm 0,1$ di 24 jam fermentasi, kemudian terus naik sampai 15,5 $\pm 0,1$ di 120 jam fermentasi. Gula reduksi pulp biji kakao segar diawal fermentasi $3 \pm 0,1$ sedikit turun di jam ke 24 menjadi 2,8 \pm 0,1 dan terus turun sampai $1,5 \pm 0,1$ di jam ke 120 fermentasi seperti tersaji pada gambar 1 . Gambar 1 terlihat bahwa gula reduksi pada biji kakao kering jemur di awal fermentasi meningkat tajam hingga sampai 24 jam fermentasi kemudian sedikit turun sampai 48 jam fermentasi selanjutnya sedikit naik sampai 72 jam fermentasi selanjutnya sedikit turun

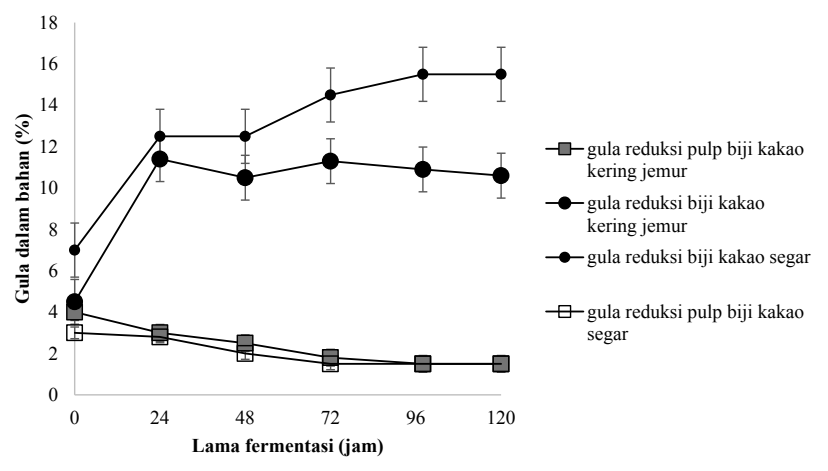

Gambar 1. Perubahan kadar gula reduksi dalam pulp, biji kakao segar dan pulp, biji kakao kering jemur 
sampai 120 jam fermentasi hasil ini sejalan dengan (Apriyanto dkk., 2016a) pada fermentasi biji kakao kering jemur dengan penambahn inokulum. Gambar 1 terlihat bahwa gula reduksi pulp biji kakao kering jemur turun secara perlahan dari awal fermentasi sampai 120 jam fermentasi. Peningkatan gula reduksi pada biji dikarenakan perombakan sukrosa dalam biji menjadi fruktosa dan glukosa. Menurut Penido dkk. (2013) bahwa peningkatan jumlah gula reduksi selama fermentasi dilaporkan sebagai hasil dari reaksi enzimatik oleh enzim invertase $\beta$-galaktosidase, $\alpha$-arbinosidase, dan $\alpha$-annosidase. Gula yang terdapat dalam keping biji kakao sebelum fermentasi yang sebagian besar berupa sukrosa dan akan mulai mengalami hidrolisis pada saat awal fermentasi secara anaerob sampai selesai proses fermentasi. Gula reduksi yang terkandung dalam keping biji kakao adalah glukosa dan fruktosa. Kadar gula reduksi pada biji kakao kering jemur lebih rendah dari gula reduksi pada biji kakao segar, hal ini mengindikasikan bahwa proses fermentasi biji kakao kering dalam penelitian ini berjalan lebih lambat, jika dibandingkan dengan proses fermentasi biji kakao basah seperti yang dilaporkan oleh Moreira dkk. (2013) dan proses fermentasinya dapat dikatakan belum berhenti dalam waktu 120 jam. Pada Gambar 1 terlihat bahwa terjadi penurunan gula reduksi pulp baik pulp biji kakao kering jemur maupun pulp biji kakao segar, hal tersebut dapat dikarenakan aktivitas yeast dan Lactobacillus lactis (Afoakwa dkk., 2014).

Pengaruh Populasi S. cerevisiae, L. Lactis, dan A. aceti terhadap Konsentrasi Etanol, Asam Laktat, dan Asam Asetat Biji Kakao

Gula di dalam pulp merupakan substrat yang dapat dirombak menjadi etanol, sedangkan inokulasi khamir meningkatkan jumlah mikrobia yang bekerja merombak gula menjadi etanol. Peningkatan proses fermentasi yang terjadi akibat inokulasi mikroorganisme banyak dilaporkan pada beberapa penelitian. Penido dkk. (2013) pada penelitiannya melaporkan penambahan biakan Saccharomyces cerevisiae dan beberapa biakan bakteri lain dapat meningkatkan kinerja fermentasi biji kakao.

Populasi sel $S$. cerevisiae, L. lactis dan A. aceti pada fermentasi biji kakao segar berturut-turut $10^{2}-10^{6} \log \mathrm{CFU} / \mathrm{g}$, $10^{3}-10^{7} \log \mathrm{CFU} / \mathrm{g}$, dan $10^{3}-0^{5} \log \mathrm{CFU} / \mathrm{g}$ (Meersman dkk, 2013; Schwan dan Wheals, 2004; Vuyst dkk., 2010; Lima dkk., 2011). Dari Gambar 2 terlihat di awal fermentasi populasi $S$. cerevisiae sebesar $10^{5} \log \mathrm{CFU} / \mathrm{g}$, L. lactis $10^{6}$ $\log \mathrm{CFU} / \mathrm{g}$ dan $A$. aceti $10^{4} \log \mathrm{CFU} / \mathrm{g}$ populasi tersebut mendekati hasil peneliti terdahulu.

Gambar 2 terlihat bahwa populasi Saccharomyces cerevisiae naik menjadi $10^{7} \log \mathrm{CFU} / \mathrm{g}$ setelah fermentasi 24 jam kemudian turun menjadi $10^{2} \log \mathrm{CFU} / \mathrm{g}$ diakhir fermentasi (120 jam fermentasi). Hal ini menunjukan bahwa aktivtas $S$. cerevisiae turun saat pengeringan dan kembali aktif setelah dilakukan rehidrasi kadar air pulp. Hal ini sejalan dengan hasil penelitian Schwan dan Wheals (2004) dan Afoakwa dkk. (2010), yaitu populasi khamir naik 24 jam fermentasi kemudian turun sampai diakhir fermentasi. Mengingat suhu optimum untuk pertumbuhan $S$. cerevisiae adalah antara suhu 30-35 ${ }^{\circ} \mathrm{C}$, sehingga populasi $S$. cerevisiae dalam penelitian ini tumbuh cepat dari $10^{5} \log \mathrm{CFU} / \mathrm{g}$ sampai $10^{7} \log \mathrm{CFU} / \mathrm{g}$ setelah 24 fermentasi.

Aktivitas $S$. cerevisiae juga dapat ditunjukan oleh kenaikan hasil degradasi gula menjadi etanol. Kandungan etanol diawal fermentasi sebesar $0,35 \%$ dan mencapai kandungan tertinggi setelah 24 jam fermentasi yaitu sebesar $1,6 \%$. S. cerevisiae mempunyai peran penting dalam fermentasi kakao terutama untuk menghasilkan alkohol dengan kondisi oksigen terbatas namun kadar gula relatif tinggi. Alkohol selanjutnya diubah menjadi asam asetat oleh A. aceti.

Setelah 24 jam fermentasi populasi $S$. cerevisiae mengalami penurunan hal ini disebakan oleh peningkatan jumlah etanol dan mulai membaiknya aerasi pada tumpukan massa biji, selanjutnya peran $S$. cerevisiae dilanjutkan oleh $L$. lactis karena kondisi lingkungan fermentasi mulai ideal untuk pertumbuhan bakteri L. lactis, dan kandungan gula pulp masih tersedia meskipun dalam jumlah kecil. L. lactis merupakan salah satu bakteri asam laktat yang berssifat anaerob atau mikroaerofilik (Camala dan Aston, 1993). Pertumbuhan optimum bakteri asam laktat terjadi setelah fermentasi 36 jam dengan populasi sel L. lactis berkisar $10^{8}-10^{9} \log \mathrm{CFU} / \mathrm{g}$ (Meersman dkk, 2013).

Gambar 2 menunjukan bahwa populasi L. lactis diawal fermentasi sebesar $10^{6} \log \mathrm{CFU} / \mathrm{g}$, kemudian naik menjadi $10^{8} \log \mathrm{CFU} / \mathrm{g}$ setelah 36 jam fermentasi dan terus naik

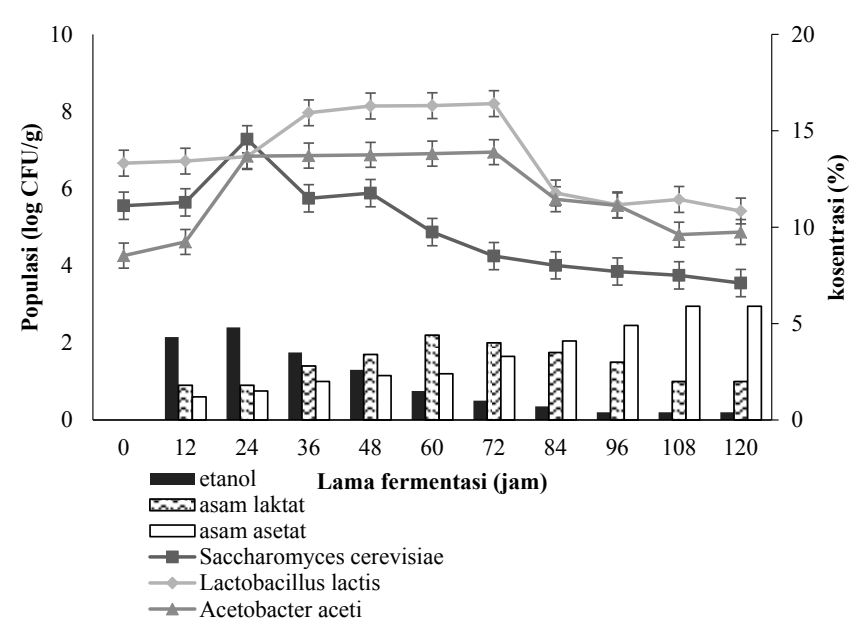

Gambar 2. Hubungan populasi S. cerevisiae, L. lactis dan A. aceti terhadap konsentrasi etanol, asam laktat, dan asam asetatbiji kakao pada kontrol selama fermentasi 
menjadi $10^{9} \log \mathrm{CFU} / \mathrm{g}$ setelah 72 jam fermentasi turun sampai $10^{5} \log \mathrm{CFU} / \mathrm{g}$, sampai akhir fermentasi menjadi $10^{6}$ $\log \mathrm{CFU} / \mathrm{g}$. Hal ini sejalan dengan hasil penelitian Ardana dan Fleet (2003), bahwa pertumbuhan optimum bakteri asam laktat terjadi setelah jam ke-36 dengan populasi L. lactis $10^{8}-$ $10^{9} \log \mathrm{CFU} / \mathrm{g}$ (Meersman $\mathrm{dkk}, 2013$ ) serta hasil penelitian Kustyawati dan Setyani, (2008) yang menyatakan bahwa L. lactis naik sampai 72 jam fermentasi. Aktivitas L. lactis selama fermentasi juga ditunjukan dengan produksi asam laktat, sedangkan populasi $L$. lactis diawal fermentasi sebesar $10^{7} \log \mathrm{CFU} / \mathrm{g}$ dan kandungan asam laktat $0,35 \%$. Populasi $L$. lactis naik sampai $10^{9} \log \mathrm{CFU} / \mathrm{g}$ setelah 72 jam fermentasi dan kandungan tertinggi asam laktat setelah 60 jam fermentasi yaitu sebesar 3,01\% dan turun sampai $\pm 2 \%$.

Semakin berkurangnya gula pada pulp serta mulai membaiknya aerasi juga meningkatnya suhu lingkungan fermentasi peran $A$. aceti dimulai. A. aceti adalah bakteri asam asetat yang merombak etanol menjadi asam asetat. Populasi $A$. aceti diawal fermentasi $10^{4} \log \mathrm{CFU} / \mathrm{g}$ kemudian meningkat sampai $10^{6} \log \mathrm{CFU} / \mathrm{g}$ jam ke 24 sampai jam ke 72 menjadi $10^{7} \log \mathrm{CFU} / \mathrm{g}$ kemudian turun menjadi $10^{4}$ $\log \mathrm{CFU} / \mathrm{g}$. Selain populasinya bertambah $A$. aceti juga memproduksi asam asetat. Kosentarsi asam asetat diawal fermentasi $0,08 \%$ seiring populasi $A$. aceti bertambah meningkat juga kosentrasi asam asetat. Populasi $A$. aceti meningkat di jam 72 yaitu $10^{8} \log \mathrm{CFU} / \mathrm{g}$ dengan kosentrasi asam asetat tertinggi terjadi pada jam ke 84 yaitu 20\% selanjutnya kosentrasi turun sampai $18 \%$.

Hasil analisa DMRT ini menunjukan bahwa $S$. cerevisiae, pada perlakuan kontrol dari awal fermentasi sampai 24 jam fermentasi naik dari $10^{5} \pm 0,1 \log \mathrm{CFU} / \mathrm{g}$ pulp menjadi $10^{7} \pm$ $0,1 \log$ CFU/g pulp, selanjutnya turun menjadi $10^{3} \pm 0,1 \log$ CFU/g pulp di120 jam fermentasi. Populasi L. lactis diawal fermentasi $10^{6} \pm 0,2 \log \mathrm{CFU} / \mathrm{g}$ pulp naik sampai $10^{9} \pm 0,1$ $\log$ CFU/g pulp di 72 jam fermentasi terus turun menjadi $10^{5} \pm 0,2 \log \mathrm{CFU} / \mathrm{g}$ pulp. Populasi A. aceti diperlakuan kontrol diawal fermentasi yaitu $10^{4} \log \mathrm{CFU} / \mathrm{g}$ pulp seiring lama fermentasi naik menjadi $10^{7} \log \mathrm{CFU} / \mathrm{g}$ pulp di 72 jam fermentasi, kemudian turun menjadi $10^{5} \log \mathrm{CFU} / \mathrm{g}$ pulp di 120 jam fermentasi. Metabolisme $S$. cerevisiae, L. lactis dan A. aceti menghasilkan etanol, asam laktat, dan asam asetat. Hasil analisa DMRT juga menunjukkan bahwa rata-rata populasi $S$. cerevisiae, L. lactis, dan A aceti perlakuan kontrol selama fermentasi tidak berbeda nyata $(p \leq 0,05)$ dari awal fermentasi sampai 120 jam fermentasi. Perubahan populasi $S$. cerevisiae, L. lactis dan A. aceti yang menghasilkan perlakuan kontrol sesuai dengan hasil penelitian Schwan dan Wheals (2004), Afoakwa, (2010), dan Apriyanto dkk. (2016a) yang telah mempelajari pertumbuhan yeast, bakteri asam laktat, dan bakteri asam asetat selama fermentasi biji kakao segar. Hasil analisis Anova penelitian ini menunjukan bahwa rata-rata produksi etanol, asam laktat dan asam asetat selama fermentasi tidak berbeda nyata $(p \leq 0,05)$ sesuai dengan hasil penelitian Ardana dan Fleet, (2003) yang telah mempelajari ekologi mikrobia pada fermentasi biji kakao di Indonesia.

Penambahan inokulum diawal menyebabkan peningkatan jumlah $S$. cerevisiae, L. lactis dan A. aceti, sehingga perubahan proses fermentasi lebih baik. Hal ini ditandai dengan perubahan suhu selama fermentasi serta kosentrasi etanol, asam laktat, dan asam asetat yang dihasilkan.

Hasil analisa DMRT perlakuan penambahan inokulum diawal menunjukan bahwa populasi $S$. Cerevisiae (FNCC 305), L. lactis (FNCC 0856) dan A. aceti (FNCC 0016) di awal fermentasi seluruhnya ditambahkan $10^{8} \pm 0,1 \log$ CFU/g pulp. Populasi S. cerevisiae selanjutnya naik menjadi $10^{12} \pm 0,1 \log \mathrm{CFU} / \mathrm{g}$ pulp, di 24 jam fermentasi kemudian turun sampai menjadi $10^{3} \pm 0,1 \log$ CFU/g pulp di 120 jam fermentasi. Populasi L. lactis naik menjadi $10^{11} \pm 0,1 \log$ CFU/g pulp di 48 jam fermentasi selanjutnya turun menjadi $10^{6} \pm 0,1 \log \mathrm{CFU} / \mathrm{g}$ pulp. Populasi $A$. aceti mengalami kenaikan sampai $10^{10} \pm 0,1 \log \mathrm{CFU} / \mathrm{g}$ pulp pada $72 \mathrm{jam}$ fermentasi, selanjutnya di 120 jam fermentasi menjadi $10^{6} \pm$ $0,1 \log \mathrm{CFU} / \mathrm{g}$ pulp. Kosentarsi etanol tertinggi terjadi pada 24 jam fermentasi yaitu $5,2 \% \pm 0,1$ selanjutnya turun menjadi $3,7 \% \pm 0,1$ dan terus turun sampai $0,3 \% \pm 0,1$.

Jika ditinjau kosentrasi etanol menunjukan bahwa perlakuan penambahan inokulum diawal dihasilkan lebih tinggi dari perlakuan kontrol dapat diduga bahwa penambahan inokulum meningkatkan populasi $S$. cerevisiae serta meningkatkan produksi etanol. Setelah 24 jam fermentasi kondisi $\mathrm{pH}$ lingkungan fermentasi disebabkan oleh naiknya etanol sehingga kondisi tersebut tidak sesuai untuk S. cerevisiae dan perannya digantikan oleh L. lactis.



Gambar 3. Hubungan populasi S. cerevisiae, L. lactis dan A. aceti terhadap konsentrasi etanol, asam laktat, dan asam asetat biji kakao hasil penambahan inokulum diawal fermentasi selama fermentasi 
Penambahan L. lactis (FNCC 0856) pada awal fermentasi segera dapat menggantikan peran $S$. cerevisiae dibuktikan oleh meningkatnya produksi asam laktat dari 1,3\% $\pm 0,1$ di jam 12 jam fermentasi menjadi 4,5\% $\pm 0,1$ di 60 jam fermentasi selanjutnya turun sampai $1,8 \% \pm 0,1$ di 120 jam fermentasi. Populasi L. lactis tertinggi terjadi pada 48 jam fermentasi dapat diduga bahwa penambahan L. lactis diawal dapat diduga terjadi persaingan dengan $S$. cerevisiae disebabkan oleh kondisi lingkungan kurang ideal bagi perkembangan $L$. lactis maka perkembangan L. lactis sedikit lambat. Kosentrasi etanol yang relatif tinggi, aerasi yang membaik dan penambahan $A$. aceti (FNCC 0016) dapat diduga menyebabkan semakin dominannya peran $A$. aceti di 60 jam fermentasi hingga akhir fermentasi serta kosentrasi asam asetat mulai naik dari 3,5\% $\pm 0,2$ sampai $6,3 \% \pm 0,2 \mathrm{di}$ 108 jam fermentasi. Hubungan antara populasi S. cerevisiae, L. lactis dan $A$. aceti terhadap kosentrasi etanol, asam laktat dan asam asetat pada perlakuan penambahan inokulum diawal tersaji pada Gambar 3.

Hasil analisis DMRT menunjukan bahwa penambahan S. Cerevisiae (FNCC 305), L. lactis (FNCC 0856) dan $A$. aceti (FNCC 0016) di awal berbeda nyata $(p \leq 0,05)$ terhadap perlakuan penambahan inokulum di awal. Pertumbuhan populasi S. Cerevisiae (FNCC 305), L. lactis (FNCC 0856), dan $A$. aceti (FNCC 0016) yang dihasilkan ini sesuai dengan yang diperoleh Kustyawati dan Setyani (2008), yang telah mempelajari penambahan S. Cerevisiae (FNCC 305), L. lactis (FNCC 0856), dan A. aceti (FNCC 0016) pada proses fermentasi biji kakao segar varietas lindak.

Penambahan inokulum secara bertahap menunjukan naiknya suhu fermentasi dan naiknya populasi $S$. cerevisiae, $L$. lactis, dan A. aceti. Gambar 4 menunjukan bahwa S. cerevisiae diawal fermentasi mengalami peningkatan dibandingkan pada perlakuan yang lain, hal ini dikarena penambahan $S$. cerevisiae dilakukan diawal fermentasi sebesar $10^{8} \log \mathrm{CFU} / \mathrm{g}$. Populasi L. lactis pada penambahan inokulum secara bertahap diawal fermentasi tidak berbeda dengan perlakuan yang lain yaitu sebesar $10^{8} \log \mathrm{CFU} / \mathrm{g}$ dan populasi $A$. aceti pada perlakuan penambahan inokulum secara bertahap tidak berbeda dengan perlakuan penambahan inokulum diawal yaitu sebesar $10^{4} \mathrm{log}$ $\mathrm{CFU} / \mathrm{g}$. Hasil ini sejalan dengan penelitian Ardana dan Fleet (2003) serta Kustyawati dan Setyani (2008), bahwa populasi A. aceti dipengaruhi oleh populasi $S$. cerevisiae. Populasi A. aceti di awal fermentasi yaitu $10^{4} \log \mathrm{CFU} / \mathrm{g}$ kemudian perlahan meningkat pada jam ke-48 sampai $10^{8} \operatorname{logCFU/g}$ kemudian perlahan turun menjadi $10^{5} \log \mathrm{CFU} / \mathrm{g}$ di akhir fermentasi.

Hasil analisa DMRT menunjukan bahwa perlakuan penambahan inokulum secara bertahap populasi $S$. cerevisiae ditambahkan di awal ferementasi $10^{8} \pm 0,1 \log \mathrm{CFU} / \mathrm{g}$ pulp, pada 24 jam fermentasi mengalami kenaikan menjadi $10^{12}$

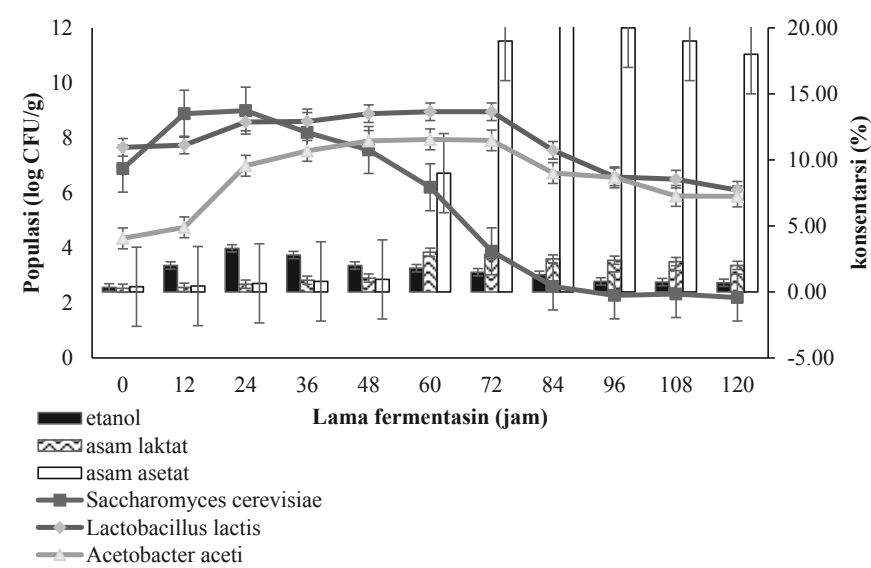

Gambar 4. Hubungan populasi S. cerevisiae, L. Lactis, dan A. aceti terhadap konsentrasi etanol, asam laktat dan asam asetatbiji kakao hasil penambahan inokulum secara bertahap selama fermentasi

$\pm 0,1 \log \mathrm{CFU} / \mathrm{g}$ pulp, di 120 jam fermentasi populasi $S$. cerevisiae menjadi $10^{2} \pm 0,1 \log \mathrm{CFU} / \mathrm{g}$ pulp. Populasi $L$. lactis di awal fermentasi $10^{6} \pm 0,1 \log \mathrm{CFU} / \mathrm{g}$ pulp kemudian ditambahkan inokulum mikrobia sebanyak $10^{8} \log \mathrm{CFU} / \mathrm{g}$ pulp pada 24 jam fermentasi selanjutnya populasi naik menjadi $10^{12} \pm 0,1 \log \mathrm{CFU} / \mathrm{g}$ pulp di 48 jam fermentasi selanjutnya turun menjadi $10^{6} \pm 0,1 \log \mathrm{CFU} / \mathrm{g}$ pulp. Populasi $A$. aceti di awal ferementasi $10^{4} \pm 0,1 \log \mathrm{CFU} / \mathrm{g}$ pulp selanjutnya ditambahkan inokulum mikrobia sebanyak $10^{8} \log \mathrm{CFU} / \mathrm{g}$ pulp pada 48 jam fermentasi selanjutnya naik sampai $10^{12}$ $\pm 0,1 \log C F U / g$ pulp pada 72 jam fermentasi, selanjutnya di 120 jam fermentasi menjadi $10^{6} \pm 0,1 \log \mathrm{CFU} / \mathrm{g}$ pulp, selanjutnya tersaji pada Gambar 4.

Penambahan $S$. cerevisiae di awal fermentasi sebanyak $10^{8} \log \mathrm{CFU} / \mathrm{g}$ pulp menunjukkan bahwa terjadi proses fermentasi sesuai dengan suksesi mikrobia yaitu $S$. cerevisiae di awal sampai jam ke 24 fermentasi menunjukan perannya lebih dominan ditunjukan oleh kadar etanol tertinggi yaitu $5,5 \% \pm 0,2$. Pada 24 jam fermentasi ditambahkan L. lactis sebanyak $10^{8} \log \mathrm{CFU} / \mathrm{g}$ pulp sejalan dengan membaiknya aerasi serta penurunan $\mathrm{pH}$ diduga menyebabkan $S$. cerevisiae tidak berperan sehingga perannya digantikan oleh L. lactis. Peran L. lactis ditunjukan dengan kadar asam laktat tertinggi $4,8 \% \pm 0,1$ di 60 jam fermentasi. Pada 48 jam fermentasi ditambahkan $A$. aceti (FNCC 0016) sebanyak $10^{8}$ log CFU/g pulp. Hasil analisis DMRT menunjukan bahwa pada perlakuan inokulum secara bertahap rata-rata $S$. cerevisiae tidak berbeda nyata terhadap perlakuan kontrol, perlakuan penambahan inokulum di awal. Rata-rata populasi L. lactis dan $A$. aceti tidak berbeda nyata dengan perlakuan inokulum di awal.

Gambar 4 menunjukan bahwa di awal fermentasi populasi $S$. cerevisiae sebesar $10^{7} \log \mathrm{CFU} / \mathrm{g}$ dengan kandungan etanol $0,4 \%$, kemudian populasi $S$. cerevisiae 
naik menjadi $10^{8} \log$ CFU/g setelah 12 jam fermentasi dengan kenaikan kandungan alkohol mencapai $2 \%$. Setelah 24 jam maka populasi $S$. cerevisiae sebesar $10^{9} \log \mathrm{CFU} / \mathrm{g}$ dan kandugan etanol 3,3\%, kondisi demikian merupakan populasi dan kandungan etanol tertinggi pada perlakuan penambahan inokulum secara bertahap. Selanjutnya populasi $S$. cerevisiae turun sampai $10^{2} \log \mathrm{CFU} / \mathrm{g}$ di jam ke-120 dan kandungan etanol turun menjadi $0,7 \%$, hal ini sejalan dengan penelitian Schwan dkk. (1995) dan Afoakwa dkk. (2010) bahwa khamir mampu bertahan sampai 6 hari atau 144 jam populasi $S$. cerevisiae sebesar $10^{2} \log \mathrm{CFU} / \mathrm{g}$.

Populasi L. lactis hasil perlakuan penambahan inokulum secara bertahap di awal fermentasi sebesar $10^{8} \log \mathrm{CFU} / \mathrm{g}$ dengan kandungan asam laktat $0,2 \%$, kemudian naik menjadi $10^{9} \log \mathrm{CFU} / \mathrm{g}$ setelah 72 jam fermentasi kandungan asam laktat sebesar 3\%, Selanjutnya turun menjadi $10^{6} \log \mathrm{CFU} / \mathrm{g}$, dengan kandungan asam laktat $2 \%$. Populasi L. lactis pada penambahan inokulum secara bertahap lebih kecil dibanding hasil penelitian Kustyawati dan Setyani (2008) yaitu $10^{9} \log$ $\mathrm{CFU} / \mathrm{g}$.

Kosentrasi asam laktat pada penelitian ini sejalan dengan pernyataan Ardana dan Fleet (2003) bahwa kosentrasi asam laktat di akhir fermentasi masih 1-3\%. Populasi $A$. aceti di awal fermentasi $10^{4} \log \mathrm{CFU} / \mathrm{g}$ dengan kandungan asam asetat $0,4 \%$ selanjutnya populasi naik menjadi $10^{8} \log \mathrm{CFU} / \mathrm{g}$ dengan kandungan asam asetat $19 \%$ setelah 72 jam fermentasi dan turun menjadi $10^{6} \log \mathrm{CFU} / \mathrm{g}$ dengan kandungan asam asetat $18 \%$ di akhir fermentasi (120 jam fermentasi). Pola pertumbuhan $A$. aceti pada penelitian ini meningkat di awal fermentasi sampai jam ke-72 dengan pertumbuhan optimum pada jam ke-72, hal ini berbeda dengan penelitian Kustyawati dan Setyani (2008) serta Ardana dan Fleet (2003) dimana populasi $A$. aceti $10^{8} \log$ CFU/g di awal fermentasi kemudian menurun sampai hari ke-1 kemudian menuju kondisi optimum pada hari ke-3 fermentasi.

Jenis dan populasi bakteri dalam suatu fermentasi berkaitan erat dengan kondisi ekstrinsik dan intrinsik. Dalam hal fermentasi kakao, tempat fermentasi, jenis kakao, dan kondisi geografis tempat tumbuh kakao mempunyai pengaruh terhadap ekologi mikrobia yang terlibat dalam fermentasi. Dengan alasan tersebut, maka jumlah bakteri asam laktat pada penelitian ini lebih rendah dibanding sejumlah bakteri tersebut $\left(10^{9}-10^{10} \mathrm{CFU} / \mathrm{g}\right.$ pada 36 jam fermentasi) pada penelitian Kustyawati dan Setyani (2008).

Populasi S. cerevisiae, L. Lactis, dan A. aceti serta jumlah etanol, asam laktat, dan asam asetat yang dihasilkan serta didukung oleh perubahan suhu yang terjadi selama fermentasi maka dapat dikatakan bahwa proses fermentasi yang berjalan baik terjadi pada perlakuan penamabahan inokulum secara bertahap. Proses fermentasi selain mendegradasi gula menjadi senyawa asam-asam organik, juga terjadi proses oksidasi polifenol karena panas dan difusi asam kedalam keping biji.

\section{Kualitas Biji Hasil Fermentasi}

\section{pH dan keasaman biji kakao}

Kualitas biji kakao hasil fermentasi ditentukan terutama oleh keasaman $(\mathrm{pH})$ dan keasaman biji selama fermentasi. Perubahan keasaman biji terlihat pada Gambar 5. Selama fermentasi mikrobia mendegradasi gula pada pulp sehingga menghasilkan alkohol dan asam organik yang terdifusi kedalaam biji. Produksi asam dari degradasi pulp sangat penting dalam fermentasi, dengan terdifusinya asam kedalam biji menjadi awal reaksi bikimia dalam biji dimulai yang akan menghasilkan biji kakao fermentasi yang baik.

Diawal fermentasi keasaman biji meningkat hingga hari ketiga fermentasi kemudian menurun hingga akhir fermentasai. Hal ini dikarena diawal fermentasi belum terjadi difusi asam kedalam biji sehingga nilai keasaman biji rendah dengan $\mathrm{pH}$ biji kakao tinggi antara 5-6. Setelah hari ketiga terjadi difusi asam mengakibatkan nilai keasaman biji menurun karena beberapa asam yang terdifusi menguap sehingga keasaman biji rendah.

Antara $\mathrm{pH}$ dan keasaman biji saling berhubungan dimana $\mathrm{pH}$ menunjukkan nilai yang rendah maka nilai keasaman biji meningkat. Pengolahan kakao menghendaki pH biji antara 5,2-5,8 untuk menghasilkan cocoa butter yang berkualitas (Wood dan Lass, 2001). Data pengamatan $\mathrm{pH}$ biji selama fermentasi tersaji dalam Gambar 6.

Hasil analisis DMRT menunjukkan bahwa ada pengaruh lama fermentasi terhadap keasaman biji kakao kering. Perlakuan penambahan inokulum di awal dan inokulum secara bertahap menunjukan keasaman biji kakao kering tidak berbeda nyata, tetapi terhadap perlakuan kontrol berbeda nyata $(p \leq 0,05)$. Hasil penelitian ini menunjukkan bahwa keasaman biji kakao kering seluruh perlakuan adalah 4,5. Keasaman biji kakao kering perlakuan kontrol naik



Gambar 5. Perubahan keasaman biji kakao selama fermentasi 


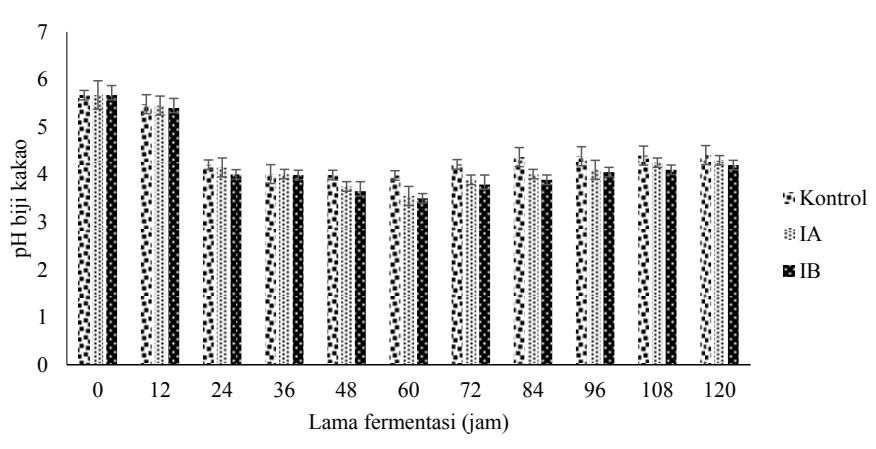

Gambar 6. Perubahan $\mathrm{pH}$ biji selama fermentasi

menjadi 5,98 \pm 0,1 di 60 jam fermentasi, kemudian kembali turun menjadi $4,4 \pm 0,1$ pada 120 jam fermentasi. Keasaman biji kakao kering perlakuan penambahan inokulum di awal fermentasi mengalami kenaikan menjadi 5,8 $\pm 0,1$ pada 60 jam fermentasi, kemudian turun menjadi 4,60 $\pm 0,1$ di 120 jam fermentasi.

Hasil analisis DMRT menunjukan bahwa rata-rata keasaman biji kakao kering perlakuan inokulum di awal dan perlakuan inokulum secara bertahap tidak berbeda nyata. Perubahan keasaman biji kakao kering yang dihasilkan sesuai dengan yang diperoleh Apriyanto dkk. (2016b).

Biji kakao kering jemur $\mathrm{pH}$ awal 5,7 kemudian mengalami penurunan hingga 3,8 di jam ke-48. Hal ini disebabkan oleh asam organik hasil fermentasi mengalami difusi ke dalam biji kemudian meningkat sampai $\mathrm{pH} 4,4$ karena beberapa asam organik mulai menguap dan sebagian tertinggal dalam biji. Kualitas mutu fermentasi juga diukur melalui nilai indeks fermentasi.

Hasil analisis DMRT menunjukkan bahwa ada pengaruh lama fermentasi terhadap pH biji kakao kering. Perlakuan penambahan inokulum di awal dan inokulum secara bertahap menunjukan $\mathrm{pH}$ biji kakao kering tidak berbeda nyata, tetapi terhadap perlakuan kontrol berbeda nyata $(p \leq 0,05)$. Hasil penelitian ini menunjukkan bahwa $\mathrm{pH}$ biji kakao kering seluruh perlakuan adalah 5,6. pH biji kakao kering perlakuan kontrol turun menjadi $3,98 \pm 0,1$ di 60 jam fermentasi, kemudian kembali naik menjadi 4,4 $\pm 0,1$ pada 120 jam fermentasi. $\mathrm{pH}$ biji kakao kering perlakuan penambahan inokulum di awal dari awal fermentasi mengalami penurunan menjadi 3,55 $\pm 0,1$ pada 60 jam fermentasi, kemudian kembali naik menjadi 4,30 $\pm 0,1$ di 120 jam fermentasi.

Hasil analisis DMRT menunjukan bahwa rata-rata $\mathrm{pH}$ biji kakao kering perlakuan inokulum di awal dan perlakuan inokulum secara bertahap tidak berbeda nyata. Perubahan pH biji kakao kering yang dihasilkan sesuai dengan yang diperoleh Kustyawati dan Setyani, (2008) dan Afoakwa dkk. (2014) yang telah mempelajari perubahan $\mathrm{pH}$ nib selama fermentasi dengan perlakuan penambahan $S$. cerevisiae, $L$. lactis, dan A. aceti.
Jika ditinjau $\mathrm{pH}$ biji kakao kering $\mathrm{pH}$ biji kakao kering seluruh perlakuan terjadi penurunan dari awal sampai 60 jam fermentasi di 120 jam fermentasi ini disebabkan oleh peningkatan populasi asam asetat yang terdifusi kedalam kotelidon. Setelah 60 jam fermentasi $\mathrm{pH}$ biji kakao kering terjadi kenaikan sampai di 120 jam fermentasi hal ini disebabkan terjadinya penguapan asam asetat seiring naiknya suhu fermentasi.

\section{Indeks Fermentasi}

Biji kakao hasil fermentasi yang baik menghasilkan biji kakao dengan indeks warna $\geq 1$, sedangkan biji kakao yang tidak melalui fermentasi kurang optimal memiliki indeks warna $<1$ (Schwan dan Wheals, 2004). Misnawi dkk. (2002) menyatakan bahwa antosianin merupakan komponen utama penyusun senyawa polifenol biji kakao dan pada kondisi asam memberikan warna merah ungu dengan absorbansi maksimum pada 500-550 nm. Dengan demikian warna dapat digunakan untuk memperkirakan kandungan antosianin biji kakao, sehingga semakin tinggi kandungan antosianin biji kakao maka dapat diartikan biji kakao tersebut tidak mengalami fermentasi.

Hasil analisa DMRT indeks fermentasi menunjukan diawal fermentasi perlakuan kontrol, perlakuan penambahan inokulum diawal dan penambahan inokulum secara bertahap berturut-turut yaitu $0,31 \pm 0,1,0,32 \pm 0,1$, dan $0,33 \pm$ 0,1 . Indeks fermentasi perlakuan kontrol menunjukan peningkatan menjadi $0,88 \pm 0,1$ di jam ke-96 fermentasi selanjutnya tidak berubah sampai 120 jam fermentasi. Pada perlakuan penambahan inokulum di awal indeks fermentasi menunjukan peningkatkan menjadi $0,93 \pm 0,1$ di 96 jam fermentasi selanjutnya tetap tidak berubah sampai 120 jam fermentasi. Perlakuan penambahan inokulum secara bertahap menunjukan indeks fermentasi mencapai 1,03 $\pm 0,1$ pada 96 jam fermentasi selanjutnya menunjukan nilai yang sama seperti disajikan Gambar 7. Dari Gambar 7 terlihat bahwa sampai akhir fermentasi indek fermentasi untuk biji kakao kering jemur tidak terpenuhi, hal ini diduga karena suhu fermentasi tidak tercapai. Suhu fermentasi tidak tercapai

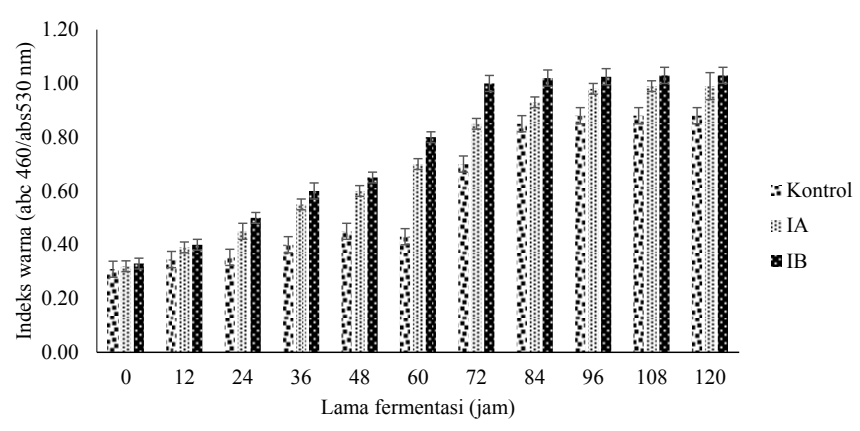

Gambar 7. Indeks fermentasi biji kakao selama fermentasi 
dikarenakan mikrobia yang membantu fermentasi dalam jumlah yang kurang. Hasil analisis DMRT menunjukan bahwa perlakuan kontrol, perlakuan penambahan inokulum di awal dan penambahan inokulum secara bertahap menunjukan indeks fermentasi berbeda nyata $(p \leq 0,05)$

\section{KESIMPULAN}

Biji kakao kering jemur dapat perbaiki mutunya melalui perendaman selanjutnya difermentasi dengan perlakuan kontrol, penambahan inokulum diawal fermentasi dan penambahan inokulum secara bertahap. Perbaikan mutu biji kakao kering jemur terlihat dari perubahan kimia pada biji kakao kering jemur pasca fermentasi.

\section{DAFTAR PUSTAKA}

Afoakwa, E.O., Budu, A.S., Mensah-brown, H., dan Felix, J. (2014). Changes in biochemical and physico-chemical qualities during drying of pulp preconditioned and fermented cocoa (Theobroma cacao) beans.Journal of Nutritional Health and Food Science 2: 1-8.

Afoakwa, E.O., Kongor, J.E., Takramadan J. dan Badudu, A.S. (2013). Changes in nib acidification and biochemical composition during fermentation of pulp pre-conditioned cocoa (Theobroma cacao) beans. Internasional Food Research Journal 20(4): 18431853.

Afoakwa, E.O. (2010). Chocolate Science and Technology. Wiey-Blackwell, United Kingdom.

Albertini, B., Schouben, A., Guarnaccia, D., Pinneli, F., Della Vecchia, M., Ricci, M., Di Renzo, G, C. dan Blasi, P., (2015). Effect of fermentation and drying on cocoa polyphenol. Journal Agriculture Food Chemistry 63(45): 9948-9953.

Anonim (2013). Produksi Perkebunan Besar Menurut Jenis Tanaman, Indonesia. http://www.bps.go.id. [29 Maret 2014].

Apriyanto, M., Sutardi, Supriyanto dan Harmayani, E. (2016a). Study on Effect of Fermentation to quality parameter of cocoa bean Indonesia. Asian Journal Diary and Food Reseacrh 35(2): 160-163.

Apriyanto, M., Sutardi, Harmanyani, E. dan Supriyanto (2016b). Perbaikan proses fermentasi biji kakao non fermentasi dengan penambahan biakan murni Saccharomyces cerevisiae, Lactobacillus lactis, dan Acetobacter aceti. Agritech 36(4): 410-415.
Ardhana, M.M. dan Fleet, G. (2003). The microbial ecology of cocoa bean fermentations in Indonesia. International Journal of Food Microbiology 86: 87-99.

Beckett, S.T. (2009). Industrial Chocolate Manufacture and Use. $4^{\text {th }}$, Wiley-Blackwell, United Kingdom.

Camalam, S.H. dan Aston J.W. (1993). The effect of the organic acid in cocoa on the flavour of chocolate. Jounal Science Food Agriculture 61: 65-71.

Camu, N., Winter, T., De Addo, S.K., Takrama, J.S., Bernaert, H. dan Vuyst, L. De. (2008). Fermentation of cocoa beans: influence of microbial activities and polyphenol concentrations on the flavour of chocolate. Journal of The Science of Food and Agriculture 88: 2288-2297.

Hansen, C.E., delOlmo, M. dan Burri, C. (1998). Enzyme activities in cocoa beans during fermentation. Journal of the Science of Food and Agriculture 77(2): 273-281.

Kustyawati, M.E. dan Setyani, S. (2008). Pengaruh penambahan inokulum campuran terhadap perubahan kimia dan mikrobiologi selama fermentasi coklat. Jurnal Teknologi Industri dan Hasil Pertanian 8: 7384.

Lima, L.J.R., Kamphuis, H.J. Nout, R.J. dan Zwietering, M.H. (2011). Microbiota of cocoa powder with particular reference to aerobic thermoresistant sporeformers. Food Microbiology 28: 573-582.

Meersman, E., Stensels, J., Mathawan, M., Witcock, P.J., Seals, V., Struyf, N., Bernaert, H., Vrancken, G. dan Verstrepen, K.J. (2013). Detailed analysis of the microbial population in Malaysian Spontaneous cocoa pulp fermentations reveals a core and variable microbiota. Plus One Journal 8(12): 1-10.

Misnawi, Jinab, S., Nazamid, S. dan Jamilah, B. (2002). Activation of remaining key enzymes in dried underfermented cocoa beans and its effect on aroma precursor formation. Food Chemistry 78: 407-417.

Moreira, I.M.D.V., Miguel, M.G.D.C.P., Duarte, W.F., Dias, D.R. dan Schwan, R.F. (2013). Microbial succession and the dynamics of metabolites and sugars during the fermentation of three different cocoa (Theobroma cacao L.) hybrids. Food Research International 54: 9-17.

Nazaruddin, R., Seng, L.K., Hassan, O. dan Said, M. (2006). Effect of pulp preconditioning on the content of polyphenols in cocoa beans (Theobroma cacao) during fermentation. Industrial Crops and Products 24: 87-94.

Neilsen, D., Crafack, M., Jespersen L dan Jakobsen, M. (2013) Chocolate in Health and Nutrition. Published by Humana Press Inc.pp. 39-60. 
Penido, A., Mendes, P., Campos, I. dan Mendes, L. (2013). Effect of various media and supplements on laccase activity and its application in dyes decolorization. Malaysian Journal of Microbiology 9(2): 166-175.

Schwan, R.F. dan Wheals, A.E. (2004). The microbiology of cocoa fermentation and its role in chocolate quality. Critical Reviews in Food Science and Nutrition 44: 205-221.

Schwan, R.F., Rose, A.H. dan Board, R.G. (1995). Microbial fermentation of cocoa beans, with emphasis on enzymatic degradation of the pulp. Journal of Applied Bacteriology - Symposium Supplement 79: 96-107.
Schwan, R.F. (1998). Cocoa fermentations conducted with a defined microbial cocktail inoculum. Applied and Environmental Microbiology 64: 1477-1483.

Sudarmadji, S., Bambang, H. dan Suhardi (1997). Prosedur Analisa Bahan Pangan. Liberty Pres. Yogyakarta.

Vuyst., L. De., Lefeber, T., Papalexandratou, Z. dan Camu, N. (2010). The functional role of latic acid bacteria. Dalam: Book Biotechonolgy of Latic Acid Bacteria Novel Applicaton, Mozzi, F.,Raya, R.R. dan Vignolo, G.M. eds., Wiley Blackwell.

Wood, G.A.R. dan Lass, R.A. (2001). Cocoa. $4^{\text {th }}$ ed. Longman, London. 